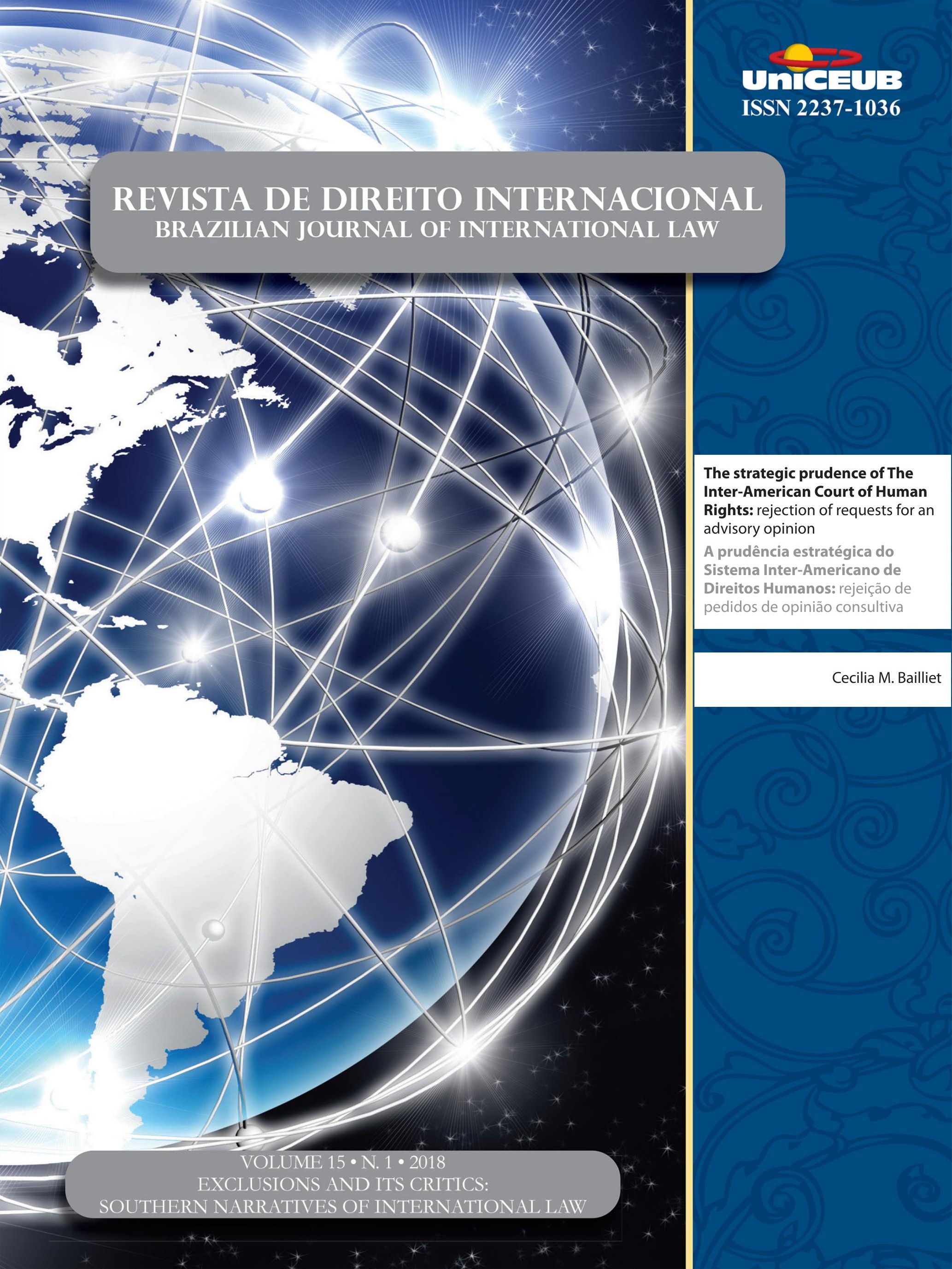




\section{Sumário}

I. Dossiê Especial: Exclusions and its Critics: Southern Narratives of

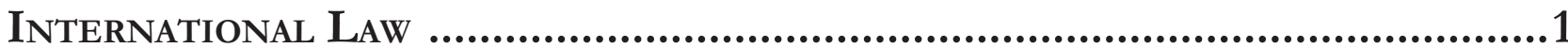

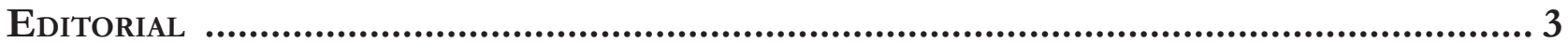

Conseguimos pensar em narrativas críticas do Direito Internacional no Sul Global? ......................... 3

ENTRE A APOLOGIA E A UTOPIA: A POLÍTICA Do DIREITO INTERNACIONAL................................ 6 Martti Koskenniemi e Tradutor João Roriz

A POLÍTICA Do DIREITO INTERNACIONAL: 20 ANOS DEPOIS ...................................................31 Martti Koskenniemi e Tradutor João Roriz

Abordagens terceiro-mundistas para o Direito Internacional: Um Manifesto............42 Bhupinder S. Chimni

Around the pyramid: Political-theoretical challenges to law in the age of global GOVERNANCE

Salem Hikmat Nasser e José Garcez Ghirardi

VOICE AND EXIT: HOW EMERGING POWERS ARE PROMOTING INSTITUTIONAL CHANGES IN THE INTERNATIONAL MONETARY SYSTEM

Camila Villard Duran

LA LIBRE AUTODETERMINACIÓN DE LOS PUEBLOS EN EL SIGLO XXI: UNA APROXIMACIÓN DE LA HISTORIA DEL COLONIALISMO Y EL NEO-COLONIALISMO DESDE LOS PUEBLOS DEL TERCER MUNDO

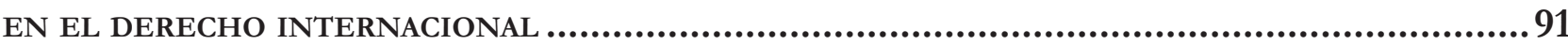

Germán Medardo Sandoval Trigo

INTERNATIONAL CLIMATE CHANGE REGIME AS A PROMOTER OF COLONIAL SYSTEMIC AND SYMBOLIC VIOLENCE: ITS RELATIONSHIP WITH INTERNATIONAL ENVIRONMENT SECURITY AND FOOD SYSTEM THRU THE LENS OF FEMINIST APPROACH 106

Douglas Castro e Bruno Pegorari 
Jus COGENS: AN EUROPEAN CONCEPT? AN EMANCIPATORY CONCEPTUAL REVIEW FROM THE INTER-AMERICAN SYSTEM OF HUMAN RIGHTS

Tatiana de A. F. R. Cardoso Squeff e Marina de Almeida Rosa

O CONHECIMENTO TRADICIONAL RELACIONADO AO COMPLEXO DO CURARE E A LEGISLAÇÃO IN-

TERNACIONAL SOBRE PROPRIEDADE INTELECTUAL. 139

Marcos Vinício Chein Feres e João Vitor de Freitas Moreira

II. Artigos sobre outros temas

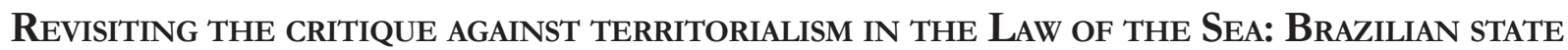
PRACTICE IN LIGHT OF THE CONCEPTS OF CREEPING JURISDICTION AND SPOLIATIVE JURISDICTION ..161 Victor Alencar Mayer Feitosa Ventura

EDUCAÇÃO SUPERIOR INTERCULTURAL, RECONHECIMENTO E REDISTRIBUIÇÃO: O DURO CAMINHO DOS POVOS INDÍGENAS NO EQUADOR 180

Vanessa Wendhausen Cavallazzi, Patrícia Perrone Campos Mello e Raony Soares

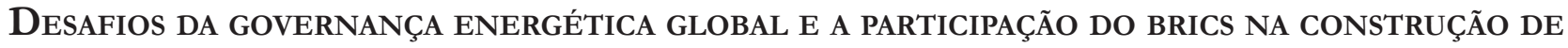
UM NOVO PARADIGMA ENERGÉTICO 200

Fernanda Volpon e Marilda Rosado de Sá Ribeiro

A hermeneutical analysis on the recognition of China as a market economy after 2016.

Alberto Amaral Júnior e Aline Pereira de Carvalho Heringer

THE ISIS ERADICATION OF CHRISTIANS AND YAZIDIS: HUMAN TRAFFICKING, GENOCIDE, AND THE MISSING INTERNATIONAL EFFORTS TO STOP IT

Sarah Myers Raben

The strategic prudence of The Inter-American Court of Human Rights: Rejection OF REQUESTS FOR AN ADVISORY OPINION 255

Cecilia M. Bailliet

Direito Internacional Monocromático: PREVISÃo e apliCaÇÃo dos Direitos LGBTI NA ORDEM INTERNACIONAL 278

Rafael Carrano Lelis e Gabriel Coutinho Galil 
III. RESENHAS

Resenha do livro Empire de Michael Hardt e Antonio Negri 301 Arthur Roberto Capella Giannattasio

Resenha do livro Imperialism, Sovereignty and the Making of International LaW, de

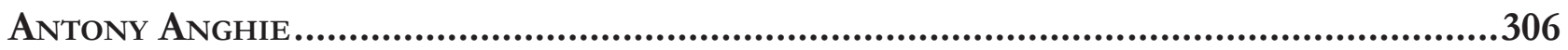

Fabrício José Rodrigues de Lemos e Laura Madrid Sartoretto 


\title{
The strategic prudence of The Inter-American Court of Human Rights: rejection of requests for an advisory opinion*
}

\author{
A prudência estratégica do Sistema Inter- \\ Americano de Direitos Humanos: rejeição de \\ pedidos de opinião consultiva
}

Cecilia M. Bailliet**

\begin{abstract}
Advisory opinions may be considered to challenge sovereignty because they often address political issues which may be contentious at the national level. This paper argues that the Inter-American Court of Human Rights is currently under pressure to uphold its legitimacy and examines whether the Court practices strategic prudence by rejecting certain requests for advisory opinions. In particular, it discusses four cases involving political issues: alleged incompatibility of national legislation with the American Convention, the prohibition of corporal punishment of children, the availability of judicial remedies for persons sentenced to death penalty, and due process rights relating to the impeachment of the president of Brazil. The article highlights that the examples of restraint reveal a complex balance between the Court's role in applying and interpreting human rights in relation to nurturing democracy while respecting sovereignty. This signals a possible tension between the conventionality control doctrine and the limitation of the Court's advisory jurisdiction.
\end{abstract}

Keywords: Inter-American Court of Human Rights, Advisory Opinions, Death Penalty, Corporal Punishment, Impeachment, Conventionality Control Doctrine, Legitimacy

\section{Resumo}

Opiniões consultivas podem ser consideradas para desafiar a soberania porque elas freqüentemente tratam de questões políticas que podem ser controversas em nível nacional. Este artigo discute que a Corte Interamericana de Direitos Humanos está atualmente sob pressão para defender sua legitimidade e examina se a Corte desenvolve prudência estratégica ao rejeitar certos pedidos de opiniões consultivas. Em particular, discutem-se quatro casos envolvendo questões políticas: a alegada incompatibilidade da legislação nacional com a Convenção Americana, a proibição de castigos corporais de crianças, a disponibilidade de recursos judiciais para pessoas sentenciadas à pena de morte e os direitos processuais relativos à impeachment do presidente do Brasil. O artigo destaca que os exemplos de contenção revelam um 
equilíbrio complexo entre o papel da Corte na aplicação e interpretação dos direitos humanos em relação à promoção da democracia, respeitando a soberania. Isso sinaliza uma possível tensão entre a doutrina de controle da convencionalidade e a limitação da jurisdição consultiva da Corte.

Palavras-chave: Corte Inter-Americana de Direitos Humanos, Opiniões consultivas, pena de morte, Castigo Corporal, Impeachment, Doutrina de Controle de Convencionalidade, Legitimidade.

\section{INTRODUCTION}

Advisory opinions may be considered to be good examples of output by international courts which may challenge the principle of sovereignty because they may address political issues at the domestic level without obtaining state consent to jurisdiction. ${ }^{1}$ Because of their non-binding character, they are considered to encourage rather than compel state compliance. The Inter-American Court of Human Rights has actively utilized Advisory Opinions to evolve human rights interpretation and strengthen compliance within the region. Indeed, as noted by Burgorgue-Larsen, it is notable that the Court had issued eight advisory opinions before deciding it first contentious case, as neither States nor the Inter-American Commission referred any contentious cases to the Court between 1979 and 1986. ${ }^{2}$ Pursuant to Article 64 of the American Convention on Human Rights, the Inter-American Court of Human Rights is empowered to provide advisory opinions to any OAS member state on the interpretation of the American Convention on Human Rights, as well as other treaties concerning the protection of human rights in the Americas, and on the compatibility of national law with

12 SCHMID, Julie Calidonio. 'Advisory Opinions on Human Rights: Moving Beyond a Pyrrhic Victory'16 Duke. J. Comp. \& Int'l L. 415, 2006.

2 BURGORGUE-LARSEN, Laurence; TORRES, Amaya Ubeda de. The Inter-American Court of Human Rights Case Law and Commentary 85. Oxford: Oxford University Press, 2011. See also Thomas Buergenthal, 'Remembering the Early Years of the Inter-American Court of Human Rights, NYU Center for Human Rights and Global Justice', Working Paper n. 1, 2005. See also Gerald L. Neumann, 'Import, Export, and Regional Consent in the Inter-American Court of Human Rights', (2008) 19 (1) The European Journal of Human Rights 101, 103. The Inter-American Commission of Human Rights is a group of independent experts which does not represent states, but instead is autonomous. the American Convention or other treaties. ${ }^{3}$ There is no requirement that the requesting state be a party to the American Convention on Human Rights or have accepted the contentious jurisdiction of the Court. In addition, all OAS organs may also request advisory opinions; indeed the Inter-American Commission actively seeks advisory opinions from the Court in order to evolve human rights law interpretation. ${ }^{4}$ The Court cannot issue an advisory opinion on its own motion. ${ }^{5}$

This article argues that the Inter-American Court of Human Rights is currently under pressure to uphold its legitimacy and thus examines whether the Court is practicing strategic prudence by rejecting certain requests for advisory opinions addressing political cases. In particular, it discusses the Court's recent rejection of four cases: the first presented by the State of Costa Rica specifically on the potential incompatibility of legislation with the American Convention, the second presented by the Inter-American Commission of Human Rights on the prohibition of corporal punishment of children, the third also presented by the Inter-American Commission on Human Rights on judicial remedies to persons sentenced to death penalty, and the last presented by the OAS Secretary-General on alleged violation of due process rights relating to impeachment of the president of Brazil. ${ }^{6}$

In comparison, it is important to note that the European Court of Human Rights emits advisory opinions in response to requests by the Committee of Ministers of the Council of Europe. ${ }^{7}$ Nevertheless, the manda-

3 See I/A Court H.R., 'Other treaties' subject to the consultative jurisdiction of the Court (Art. 64 American Convention on Human Rights). Advisory Opinion OC-1/82 of 24 September 1982. Series A No. 1. 4 See SANDHOLTZ, Wayne. Expanding Rights: Norm Innovation in the European and Inter-American Courts'. In: BRYSK, Alison; STOHL, Michael (Ed.) Expanding Human Rights: 21st Century Norms and Governance 156 (Edward Elgar 2017).

5 Jo M Pasqualucci, 'Advisory Practice of the Inter-American Court of Human Rights: Contributing to the Evolution of International Human Rights Law', 38 Stan. J. Int'l. L. Journal 241, 253 (2002). 6 I/A Court H.R., Request of Advisory Opinion submitted by the Republic of Costa Rica. Order of the Inter-American Court of Human Rights of 10 May 2005; I/A Court H.R., Request of Advisory Opinion submitted by the Inter-American Commission of Human Rights. Order of the Inter-American Court of Human Rights of 24 June 24 2005; I/A Court H.R., Request of Advisory Opinion submitted by the Inter-American Commission of Human Rights. Order of the Inter-American Court of Human Rights of 27 January 2009; I/A Court H.R., Request of Advisory Opinion submitted by the Secretary General of the Organization of American States. Order of the Inter-American Court of Human Rights of 23 June 2016. 7 See Protocol No. 2 (1970). 
te is limited to addressing legal questions concerning the interpretation of the Convention and its Protocols, not the content or scope of freedoms contained therein. ${ }^{8}$ Hence, this article will instead make comparative references to relevant cases from the European Court of Human Rights contentious practice as well as with the Inter-American Court's own contentious practice in relation to similar issues, such as the impeachment of judges. The article also refers to relevant reports from NGOs and media.

Part 2 provides a background overview of the Advisory Opinions of the Inter-American Human Rights Court and the role of the conventionality control doctrine; Part 3 sets out the limitations to the advisory jurisdiction, Part 4 presents the four rejection orders to requests for advisory opinions and explains the dilemmas leading to a potential strategy of restraint, and Part 5 offers a conclusion underscoring a tension between the conventionality control doctrine and the limitation of the Court's advisory jurisdiction.

\section{Background Overview of the Advisory Opinions of the Inter-American Human Rights COURT}

As of February 2018, the Court's website contains 25 advisory opinions. ${ }^{9}$ Bert B. Lockwood stated that 'The advisory jurisdiction established by article 64 of the Convention may offer the most effective means of demonstrating the Court's usefulness and providing the Court with an opportunity to develop a consistent and influential body of human rights jurisprudence. ${ }^{10}$ The

8 Advisory opinions within this system have addressed the election of judges, including the need for representation of women. The latter is an interesting issue to consider in the comparative perspective given the fact that the Inter-American Court of $\mathrm{Hu}$ man Rights only has one woman judge, Elizabeth Odio Benito, as opposed to the European Court of Human Rights which has 17 women judges at present. See Advisory Opinion on certain legal questions concerning the lists of candidates submitted with a view to the election of judges to the European Court of Human Rights, 12 February 2008 and Advisory Opinion on certain legal questions concerning the lists of candidates submitted with a view to the election of judges to the European Court of Human Rights, 22 January 2010.

9 <http://www.corteidh.or.cr/cf/Jurisprudencia2/busqueda_ opiniones_consultivas.cfm?lang $=\mathrm{en}>$

10 Bert B. Lockwood, Jr. 'Advisory Opinions of the Inter-American Court of Human Rights', 13 Denv. J. Int'l. L. \& Pol'y 245, 246 (1983-84).
Court has espoused a broad scope of reference to normative sources in order to ground its pronouncements on the fundamental guarantees due to vulnerable persons within the region. It also accepts amicus curiae, enabling NGOs, experts, academics, and to a lesser extent corporations and states to engage in the development of human rights jurisprudence. ${ }^{11}$

The scope of the Court's advisory jurisprudence has evolved over time. It commenced with decisions that addressed classic protection issues within international law. The Court affirmed consular rights in the Opinion on Consular Relations ${ }^{12}$, confirmed the non-derogable status of Habeus Corpus in the Opinion on Habeus Corpus in Emergency Situations ${ }^{13}$ and Opinion on Judicial Guarantees in States of Emergency ${ }^{14}$, and clarified children's rights to fair trial and judicial protection (Articles $8 \& 25)$ in relation to Article 19 in the Opinion on Judicial Status and Human Rights of the Child. ${ }^{15}$

The Court also addressed procedural issues related to its function. Argentina requested an advisory opinion from the Court on Article 55 of the American Convention, addressing whether the appointment of an ad hoc judge should only apply to inter-state conflicts and whether in cases involving individual opinions, should the judge sharing the nationality of the accused state recuse himself or herself from the case in order to maintain

11 See MOYER, Charles. The Role of Amicus Curiae in the Inter American Court of Human Rights (Inter American Institute of $\mathrm{Hu}-$ man Rights 1985). Available at: <http://www.corteidh.or.cr/tablas/ a11770.pdf $>$; see also the amici curiae of the NGO CEJIL, available at: <https://cejil.org/en/amicus-curiae-0>; and Francisco J. Rivera Juaristi The Amicus Curiae in the Inter-American Court of $\mathrm{Hu}-$ man Rights (1982-2013), available at: <https://www.scribd.com/ document/252530356/The-Amicus-Curiae-in-the-Inter-AmericanCourt-of-Human-Rights-1982-2013>

12 The judgment addresses the non-regional treaty, the Vienna Convention on Consular Relations, The Right to Information on Consular Assistance in the Framework of the Guarantees of Due Process of Law, Advisory Opinion OC-16/99 of 1 October 1999, Series A, No. 16.

13 Advisory Opinion OC-8/87 of 30 January 1987, Series A, No. 8.

14 Advisory Opinion OC-9/87 of 6 October 1987, Series A, No. 9 .

15 Advisory Opinion OC-17/2002 of 28 August 2002, Series A, No. 17. In the children's rights cases, the Court refers to the CRC and the Declaration on the Rights of the Child to emphasize the importance of upholding 'the best interests of the child' standard. It further refers to UN guidelines on juvenile justice and prevention of juvenile delinquency, as well as non-custodial measures. Israel de Jesus Butler, 'Recent Advisory Opinions and Contentious Cases of the Inter-American Court of Human Rights', 4(1) Human Rights Law Review 126, (2004). 
impartiality? ${ }^{16}$ Brazil, Colombia, Mexico, El Salvador, and Venezuela submitted written observations, indicating significant interest by states. The Inter-American Commission of Human Rights and several academic institutions also offered observations. The Court held:

1. That in conformity with Article 55(3) of the American Convention, the possibility for States Parties in a case submitted before the Inter-American Court to appoint a Judge ad hoc to be part of the Court when there is no judge of its nationality in its composition, is restricted to contentious cases originated in interstate communications (Article 45 of said instrument), and that it is not possible to derive a similar right in favor of States Parties in cases originated in individual petitions (Article 44 of said treaty).

2. That the national judge of the respondent State must not participate in the hearing of individual cases.

This decision thus upheld the principles of independence and neutrality of the organ in relation to fair processing of cases.

Another case involved Venezuela which requested an advisory opinion from the Court regarding whether there was an organ which has oversight over due process of law in the proceedings before the Inter-American Commission of Human Rights. ${ }^{17}$ Venezuela had been concerned with the Commission's cases and reports on various human rights issues in Venezuela, including violation of freedom of expression, interference with the judiciary, extrajudicial executions, etc. ${ }^{18}$ The Court considered its competence to offer an advisory opinion 'as it relates to an organ within the inter-American system for the protection of human rights, such as the Inter-American Commission, and to the extent that its ruling will serve to illustrate the scope of the powers

16 I/A Court H.R., 'Article 55 of the American Convention on Human Rights'. Advisory Opinion OC-20/09 of 29 September 29 2009. Series A No. 20.

17 I/A Court H.R., Control of due process in the exercise of the powers of the Inter-American Commission on Human Rights (Articles 41 and 44 to 51 of the American Convention on Human Rights). Advisory Opinion OC-19/05 of 28 November 2005. Series A No.19.

18 The Commission's reports on Venezuela are available here: <http://www.cidh.org/countryrep/Venezuela2003eng/toc.htm> <http://www.cidh.org/countryrep/Venezuela2009eng/VE09. TOC.eng.htm> <http://www.cidh.oas.org/demandas/12.256\%20 $12.258 \% 20 \mathrm{y} \% 2012.307 \% 20 \mathrm{Blanco} \% 20$ Romero $\% 20 \mathrm{y} \% 20$ otros $\% 20$ Venezuela $\% 2030 j u n 04 \% 20$ ESP.pdf>

The Commission has processed 17 cases involving Venezuela. that the American Convention grants to the Commission for the promotion and defense of human rights.' The Court held that 'the Inter-American Court of $\mathrm{Hu}$ man Rights, in the exercise of its functions, controls due process of law in the proceedings before the Inter-American Commission of Human Rights in relation to the processing of matters that have been submitted to the Court's consideration, in accordance with the competence granted to it by the American Convention and other inter-American instruments for the protection of human rights.' In spite of the Court guaranteeing due process, Venezuela initiated a reform process of the Commission, seeking to limit its authority and transfer of its seat from Washington D.C. to a Latin American country, and eventually denounced the American Convention in 2012. ${ }^{19}$

This was followed by a period in which the Court addressed broader, holistic protection issues marked by the consequences of globalization. In the Advisory Opinion on the Juridical Condition and Rights of the Undocumented Migrant $5^{20}$, the Court responded to Mexico's request for a clarification of the status of undocumented workers under international law, noting issues of legality of discrimination in the application of international labor standards to migrant workers working illegally under national law. The Court received many amicus briefs from NGOs, labor rights groups, and law firms specializing in immigration cases. The Court sought to recognize non-discrimination as a jus cogens norm and underscored the due process and equality rights of migrant workers. Further, it found the obligation to respect labor rights to be of erga omnes character and incumbent on the state and private employer. Thus, the Court highlighted the importance of ensuring that undocumented migrants have access to domestic courts, health care, and pension rights in like manner to regular employees. This decision is formidable given the scope of undocumented migrants in the United States, recently underscored by President Trump's decision to build a wall on the US-Mexico border and his support of de-

19 <http://www.ijrcenter.org/2012/09/19/venezuela-denounces-american-convention-on-human-rights-as-iachr-faces-reform/ > 20 Advisory Opinion OC-18/03 of 18 September 2003, Series A. No. 18. Referring to the ICCPR; UDHR, OAS Charter, ADHR, and ACHR the Court recognized that the Opinion would apply to OAS Member States that have signed the OAS Charter, the American Declaration, or the Universal Declaration or ratified the ICCPR, regardless of whether they have ratified the American Convention or optional protocols. 
portation of migrants. ${ }^{21}$ On the one hand, the Court may appear to have embarked upon a strategically risky path by addressing state responsibility in the context of transnational migration, but on the other hand as the US is not a party to the American Convention and has not accepted the jurisdiction of the Court, the Court had no risk of 'losing' the United States. According to Judge Ferrer MacGregror, these advisory opinions serve as a legal source for all OAS Member States (including the US which is not a party to the Convention) in order to contribute to human rights. ${ }^{22}$

This opinion was later complemented by the Advisory Opinion addressing the Rights and Guarantees of Children in the Context of Migration as requested by Argentina, Brazil, Uruguay and Paraguay. ${ }^{23}$ The applicant states indicated that there is a lack of legislation and public policies related to different issues that are examined in the request. [... A] still-frequent feature in some laws and migratory policies is the lack of the corresponding interrelation with the system of protection of the rights of the child, limiting the capability of public institutions to adequately define the measures that they must adopt whenever a child enters a country in an irregular manner' which usually results in 'the absence of adequate procedures to identify the different risk situations faced by those children in mixed migration flows. ${ }^{24}$ Briefs were provided by Costa Rica, Ecuador, Honduras, and Mexico, as well as many IOs, including UNHCR, IOM, and UNICEF, as well as NGOs and academic institutions.

The Court explained how the contextual background of the request served to legitimize its engagement through the advisory function to clarify the rights of child migrants:

That from this perspective, the Court understands that its answer to the request submitted will be of specific usefulness in the context of a regional reality in which aspects relating to State obligations concerning

$21<$ http://www.independent.co.uk/news/world/americas/ donald-trump-mexico-immigration-speech-border-wall-will-paylatest-news-us-election-2016-a7219416.html. See also: <https:// www.dhs.gov/executive-orders-protecting-homeland>.

22 MAC-GREGOR, E. F. 'Conventionality Control the New Doctrine of the Inter-American Court of Human Rights', AJIL Unbound, 109, p. 96, 2015.

23 I/A Court H.R., Rights and guarantees of children in the context of migration and/or in need of international protection. Advisory Opinion OC-21/14 of 19 August 2014. Series A n.21.

24 Para. 26 migrant children have not been clearly and systematically established, based on the interpretation of the relevant norms. This usefulness is revealed by the significant interest indicated by all the participants in this advisory procedure. First the request itself, presented by four States, which offers, based on the unified position of the four States, a basic consensual standard in this regard. In addition, 42 briefs with observations were received, submitted by five OAS Member States, the Inter-American Commission, the Inter-American Children's Institute, four international agencies, and 31 institutions and individual members of different organizations, civil society in general, and academic institutions. Similarly, nine OAS Member States, the Inter-American Commission, three international agencies, and 14 institutions and individual members of different organizations, civil society in general and academic institutions played an active role in the public hearing. ${ }^{25}$

The Court affirmed the conventionality control doctrine, described by Judge Ferrer MacGregor as:

(C)reat(ing) the international obligation on all States parties to the ACHR to interpret any national legal instruments (the constitution, laws, decrees, regulations, jurisprudence, etc.) in accordance with the ACHR and with the Inter-American corpus juris more generally. Wherever a domestic instrument is manifestly incompatible with the Inter-American corpus juris, state authorities must refrain from application of this law, in order to avoid any violation of internationally protected rights. ${ }^{26}$

The Court firsts developed this doctrine within its contentious jurisdiction, as it declared national amnesty laws to be manifestly incompatible with the American Convention on Human Rights, constituting violations in themselves and incurring international liability. ${ }^{27} \mathrm{This}$ doctrine prompted a significant shift in legal education and practice within Latin America, as lawyers and judges were expected to understand the relevance of the American Convention and case law of the Court to na-

\footnotetext{
25 Para. 27

26 Mac-Gregor, supra note 22 at 93. See also Jorge Contesse,' Contestation and Deference in the Inter-American Human Rights System'. 79 (2) Law \& Contemporary Problems, (1 April 2016). Available at: <https://ssrn.com/abstract=2799476>, citing Ariel E. Dulitzky, 'An Inter-American Constitutional Court? The Invention of the Conventionality Control by the Inter-American Court of $\mathrm{Hu}-$ man Rights', 50 TEX. INT'L. L.J. 45 (2015).

27 See 'Almonacid Arellano v. Chile, Preliminary Objections, Merits, Reparations, and Costs', Judgment IACtHR No. 154 (26 September 2006).
} 
tional cases. Judge Ferrer MacGregor characterizes this doctrine as 'consonant with democratic values and one that helps make human rights more effective. ${ }^{28} \mathrm{He}$ notes that one of the objectives of the doctrine is 'to bolster the complementarity (subsidiarity) of national and Inter-American systems and to create a genuinely "integrated system" of human rights protection. . . (and to) facilitate and increase dialogue, especially judicial dialogue, between national courts and the Inter-American Court on the subject of human rights.' There has been a growing awareness within national jurisdictions of the importance of ensuring that legislation is in accordance with regional human rights standards. It is arguable that the advisory jurisdiction could potentially have an important role in supporting state initiatives to meet its obligations when adopting new legislation. Indeed, Judge Ferrer MacGregor indicates that the conventionality control doctrine is also applicable to its advisory output, citing the Court's Advisory Opinion:

Different organs of the State must carry out the corresponding control of conformity with the Convention, based also on the considerations of the Court in exercise of its non-contentious or advisory jurisdiction, which undeniably shares with its contentious jurisdiction the goal of the inter-American human rights system, which is "the protection of the fundamental rights of the human being." Furthermore, the interpretation given to a provision of the Convention through an advisory opinion provides all the organs of the Member States of the OAS, including those that are not parties to the Convention but that have undertaken to respect human rights under the Charter of the OAS (Article 3(1)) and the Inter-American Democratic Charter (Articles 3, 7, 8 and 9), with a source that, by its very nature, also contributes, especially in a preventive manner, to achieving the effective respect and guarantee of human rights. In particular, it can provide guidance when deciding matters relating to children in the context of migration and to avoid possible human rights violations. ${ }^{29}$

Notwithstanding, one may suggest that there is a tension between the Court's interest in providing advisory output as an additional source to be utilized within conventionality control and the imperative to avoid the advisory jurisdiction to serve as a mechanism which may undercut the contentious jurisdiction.

28 Ferrer Mac Gregor, supra note 22 at 93.

29 Ibid. at 96
The opinion set forth the obligations of states to give priority to human rights based approaches over consideration of nationality or migratory status and to identify non-national children who require international protection. The Court relied on the American Convention, the Inter-American Convention to Prevent and Punish Torture, and the American Declaration of the Rights and Duties of Man. Further, the Court set forth that states are expected to guarantee due process and pursue "the best interest of the child" as a paramount consideration in decisions. Additionally, the Court recognized the duty to respect the prohibition of deprivation of liberty as a precautionary measure, the principle of family unity, the prohibition on refoulement, and the duty refrain from expelling the parents of child nationals for administrative immigration offenses. ${ }^{30}$ This decision provides an extremely comprehensive protection framework for migrant children, and as it was requested by States, the Court was secure in responding by articulating a clear legal protection framework to assist states to address vulnerable persons, characterizing it as a positive example of a preventive conventionality control doctrine. The Inter-American Commission of Human Rights has followed up these advisory opinions by visits to the US and monitoring the situation of migrants, including children. ${ }^{31}$

In 2016, the Court issued an Advisory Opinion on the entitlement of legal entities to hold rights under the Inter-American Human Rights system. ${ }^{32}$ This request was raised by Panama, which indicated that the issue was of concern to various states within the region, and indeed Argentina, Bolivia, Colombia, El Salvador, Guatemala and Honduras submitted observations. This was complemented by written observations presented by a variety of IOs, NGOs, academics, and other civil society actors. The Court concluded that the American Convention, Article 1, applies to human persons, not juridical persons. It specified that indigenous commu-

30 I/A Court H.R., Rights and guarantees of children in the context of migration and/or in need of international protection. Advisory Opinion OC-21/14 of 19 August 2014. Series A No.21.

$31<$ http://www.oas.org/en/iachr/media_center/PReleases/2014/105.asp>

32 I/A Court H.R., Entitlement of legal entities to hold rights under the Inter-American human rights system (Interpretation and scope of Article 1(2), in relation to Articles 1(2), 8, 11(2), 13, 16, 21, $24,25,29,30,44,46$ and 62(3) of the American Convention on Human Rights, as well as of Article 8(1)(A) and (B) of the Protocol of San Salvador). Advisory Opinion OC-22/16 of 26 February 2016. Series A No. 22. 
nities and tribes enjoy rights within the Convention and may access the Inter-American system. In addition, the San Salvador Protocol grants rights to syndicates, federations, and confederations, which enables them to defend their rights within the Inter-American system. ${ }^{33}$ The Court also held that in certain cases, physical persons can enjoy their rights by way of legal persons (such as shareholders and their right to property or media and freedom of expression) and thus access the system accordingly. This case indicates the Court's recognition of the growing importance of non-state actors and the need to address them within the human rights system. As this case was raised by a State and addressed the interpretation of the Convention, it falls squarely within the paradigm of normative consultation and hence the Court faced little risk in accepting the request.

In 2017, the Court delivered an Advisory Opinion on the Environment and Human Rights. ${ }^{34}$ Colombia requested the Court to clarify whether states engaged in development infrastructure projects in maritime zones (such as the Caribbean Coast) have an obligation to conduct environmental impact assessments given the risk of possible impact on the right to life (Article 4) and physical integrity (Article 5) of coastal inhabitants. Argentina, Bolivia, Honduras, and Panama provided written observations. The Inter-American Commission of Human Rights, a representative for the OAS Secretary General, and the International Union for the Conservation of Nature also provided written submissions. In addition, the International Maritime Organization, NGOs, academics, and other civil society groups provided statements. The Court articulates the view that the American Convention is applicable wherever member States exercise authority or effective control over persons within or outside of their territory. The Court set forth that States have an obligation to prevent significant environmental damage within or outside of its territory, hence they should regulate and supervise activities under their jurisdiction. Further they should

33 Organization of American States (OAS), Additional Protocol to the American Convention on Human Rights in the Area of Economic, Social and Cultural Rights ('Protocol of San Salvador'), 16 November 1999, A-52, available at: <http://www.refworld.org/ $\mathrm{docid} / 3 \mathrm{ae} 6 \mathrm{~b} 3 \mathrm{~b} 90 . \mathrm{html}>$

34 I/A Court H.R., The Environment and Human Rights (State obligations in relation to the environment in the context of the protection and guarantee of the rights to life and to personal integrity), interpretation and scope of Articles 4(1) and 5(1) of the American Convention on Human Rights). Advisory Opinion OC-23/17 of November 15, 2017. Series A No. 23. complete environmental impact assessments when there is a risk of significant damage to the environment, establish a contingency plan, maintain security measures and procedures to minimize the risk of large environmental accidents, and mitigate damage in the event of such accidents. The Court called upon states to act in conformance with the precautionary principle, in order to protect the right to life and the right to physical integrity. Further, the Court identified an obligation to cooperate in good faith in order to protect against trans-border damage to the environment. States are obliged to notify, consult and negotiate in good faith with states that may be potentially affected by an action which may result in significant trans-border damage and also in cases of environmental emergencies. Further, the Court recognized the duty of States to guarantee the right of access to information on the possible impact on the environment, the right of public participation of persons under their jurisdiction in decision making on issues affecting the environment, and access to justice.

Also in 2017, the Court published an Advisory Opinion on Gender identity, and equality and non-discrimination with regard to same-sex couples. ${ }^{35}$ Costa Rica petitioned the Court to explain whether gender identity is a protected category according to the American Convention on Human Rights, thereby requiring states to fulfill requests for a name change in relation to gender as well as recognition of same-sex marriage. Additionally, Costa Rica requested clarification of whether persons joined via same sex union would acquire all propriety rights. Costa Rica indicated that there was divergent practice among member states of the Inter-American system. Argentina, Bolivia, Brazil, Colombia, Guatemala, Honduras, Mexico, Panama, and Uruguay provided written observations. The states that did recognize same sex marriage at the time were Argentina, Brazil, Canada, Colombia, Mexico, the United States, and Uruguay. Some states, including Costa Rica, have experienced strong polarization within their societies on this issue. Ironically, the contentious level of politicization of same sex marriage impacted even the presidential election within the same country which

35 I/A Court H.R., Gender identity, and equality and non-discrimination with regard to same-sex couples. State obligations in relation to change of name, gender identity, and rights deriving from a relationship between same-sex couples (interpretation and scope of Articles 1(1), 3, 7, 11(2), 13, 17, 18 and 24, in relation to Article 1, of the American Convention on Human Rights). Advisory Opinion OC-24/17 of November 24, 2017. Series A No. 24. 
had filed the petition for the advisory opinion. ${ }^{36}$ The Inter-American Commission of Human Rights, the UN Office of the High Commissioner for Human Rights, national public defenders offices, and a large number of NGOs, academics, and other civil society actors also submitted written observations. The Court underscored that equality and non-discrimination guarantees are considered jus cogens within international law and provides a thorough examination of the evolution of state practice and international human rights policy regarding gender identity issues. It concluded that states are obligated to recognize, regulate, and establish procedures to provide access to public registries and ID documentation in accordance with gender identity, in accordance with the right to a juridical personality (Article 3), the right to personal liberty and security (Article 7.1), right to privacy (Article 11.2), the right to a name (Article 18), in conjunction with the state's obligation to protect rights (Article 1) and the right of equal protection (Article 24). The Court stated that states are required to provide an administrative procedure to comply with the right to register in conformance with gender identity, as long as the procedure recognized the self-identity of the person, maintained confidentiality, based on free and informed consent, without requiring hormonal treatment or surgery, was speedy and free. The Court determined that same sex unions were protected in accordance with the right to privacy (Article 11) and the right to family life (Article 17) and called upon states to recognize same-sex marriage and propriety rights in conformance with the right of equal protection (Article 24). LBGTI advocacy groups across Latin America celebrated but also cautioned that there may be backlashes against implementation of this advisory opinion, hence one may suggest that it may be a real test of the viability of the preventive conventionality control doctrine.

Taken together, these advisory opinions underscore the value of this mechanism for upholding the primacy of protection interests of vulnerable individuals against exertion of state power. They also reveal the deliberate use of advisory opinions to strengthen the normative evolution of human rights law. It is suggested that these cases are balanced by the Court's parallel rejection of requests which address certain political cases and pragmatically signal deference to States.

36 <http://www.ticotimes.net/2018/01/31/same-sex-marriageissue-shifts-elections-in-costa-rica $>$

\section{Limitations to the Advisory Jurisdiction OF THE INTER-American COURT OF HUMAN RIGHTS}

The Inter-American Court is mindful of limitations to its advisory jurisdiction. The first is that the advisory opinion may only address the interpretation of treaties which relate to the protection of human rights in a Member State. These treaties need not be only from the Americas, nor need they be human rights treaties per se, but their provisions should relate to human rights. ${ }^{37}$ Political cases may involve issues which merge human rights concerns with questions regarding the separation of powers, the rule of law, and the function of democratic institutions. On the one hand, as with the ICJ, the advisory jurisdiction may facilitate political resolution of a problem via adjudication. ${ }^{38}$ On the other hand, the Court may risk losing credibility should it be deemed to overstep boundaries; hence volatile political issues may spark a backlash against the Court. Hence, the Court must strike a balance when determining which issues to accept pursuant to the advisory jurisdiction.

The second limitation is that that cases which are likely to undermine the Court's contentious jurisdiction or weaken the system addressing the protection of victims should be deemed inadmissible. ${ }^{39}$ Respect for the primacy of contentious jurisdiction within international law roots back to the Permanent Court of International Justice's decision in the Eastern Carelia Case in 1923. ${ }^{40}$ In this case, the Court determined that it could not deliver an advisory opinion on the obligations of Russia towards Finland regarding Eastern Carelia given that Russia had not given its consent to have this issue resolved through the League of Nations nor the Court.

37 Parker, 'Other Treaties': The Inter-American Court of Human Rights Defines its Advisory Jurisdiction, 33 Ass. U.L.

REV. 211 (1983). I/A Court H.R., 'Other treaties' subject to the advisory jurisdiction of the Court (Art. 64 American Convention on Human Rights), Advisory Opinion OC-1/82 of 24 September 1982, Series A No. 1.

38 See for example, David Sloss, 'Using International Court of Justice Advisory Opinions to Adjudicate Secessionist Claims', 42 Santa Clara L. Rev. 357 (2001).

39 Burgorgue-Larsen et. al. supra note 2 at 79. See also Thomas Buergenthal, 'The Advisory Practice of the Inter-American Human Rights Court', 79 Am. J. Int'l L. 1, 27 at 11 (1985), citing the Advisory Opinion on Restrictions to the Death Penalty (1983) paras. 36-37. 40 Status of Eastern Carelia, USSR v Finland, Advisory Opinion, (1923) PCIJ Series B no 5, ICGJ 272 (PCIJ 1923), 23rd July 1923, Permanent Court of International Justice (historical) [PCIJ] 
In like manner, the Inter-American Court of Human Rights is reluctant to violate sovereign expectations regarding consent and be accused of delivering ex parte decisions.

Nevertheless, the ICJ has addressed highly political cases within its advisory jurisdiction, such as the Legal Consequences of the Construction of a Wall case and the Legality of the Threat or Use of Nuclear Weapons Case. ${ }^{41}$ Hence, there is also comparative precedent for openness to addressing claims which may fall within a grey zone of relevance to both contentious and advisory jurisdiction. Indeed, the Inter-American Court of Human Rights itself has also demonstrated such extensibility in its advisory cases addressing the rights of migrants. ${ }^{42}$

Finally, the last limitation is that the Court is to consider each request individually and may find compelling reasons to issue a denial which is to be issued with reasons. This is an open provision which grants the Court flexibility in exhibiting strategic prudence when determining whether or not to proceed with a case.

\section{Rejection Orders to Requests for Advisory OpInIon}

Since 2005, the Inter-American Court of Human Rights has rejected four requests for advisory opinions while issuing six advisory opinions in the same period. The six positive responses involve requests which were all presented by states largely addressing normative or procedural interpretation and were presented in section $\mathrm{IV}^{43}$ The rejection orders indicate a tension between the

41 Advisory Opinion Concerning Legal Consequences of the Construction of a Wall in the Occupied Palestinian Territory, International Court of Justice (ICJ), 9 July 2004, available at: < http://www.refworld.org/ docid/414ad9a719.html $>$ and Legality of the Threat or Use of Nuclear Weapons, Advisory Opinion, I.C.J. Reports 1996, p. 226, International Court of Justice (ICJ), 8 July 1996, available at: <http://www. refworld.org/docid/4b2913d62.html >

42 I/A Court H. R., Advisory Opinion on the Juridical Condition and Rights of the Undocumented Migrants, Advisory Opinion OC-18/03 of 18 September 2003, Series A. No. 18: and I/A Court H.R., Rights and guarantees of children in the context of migration and/or in need of international protection. Advisory Opinion OC-21/14 of 19 August 2014. Series A No.21.

43 I/A Court H.R., The Environment and Human Rights (State obligations in relation to the environment in the context of the protection and guarantee of the rights to life and to personal integrity), interpretation and scope of Articles 4(1) and 5(1) of the American Convention on Human Rights). Advisory Opinion OC-23/17 of November 15, 2017. Series A No.
Inter-American Commission's interest in developing human rights law through advisory opinions on key issues, and the Court's concern regarding maintaining legitimacy before Member States which are protective of sovereignty interests. The first rejection order involves a case in which a State requested an advisory opinion addressing incompatibility of legislation with the American Convention of Human Rights, a straightforward request. However, the latter cases are more complex. The Inter-American Commission of Human Rights sought an advisory opinion on Corporal Punishment of Children and another advisory opinion on the application of the Death Penalty, and the OAS Secretary General solicited an advisory opinion in order to address alleged irregularities within the Brazilian impeachment proceedings against the President. These cases prove problematic from a strategic perspective.

\subsection{The Incompatibility of Legislation with the American Convention of Human Rights}

The Court has rejected requests to issue advisory opinions on legislation, in contrast to its willingness to strike legislation as incompatible with the American Convention on Human Rights within its contentious jurisdiction, and this highlights the dilemma the Court has with its conflicting obligations to assist states to strengthen its democratic institutions and norms while at the same time respecting sovereignty. ${ }^{44}$

23. I/A Court H.R., Gender identity, and equality and non-discrimination with regard to same-sex couples. State obligations in relation to change of name, gender identity, and rights deriving from a relationship between same-sex couples (interpretation and scope of Articles 1(1), 3, 7, 11(2), 13, 17, 18 and 24, in relation to Article 1, of the American Convention on Human Rights). Advisory Opinion OC-24/17 of November 24, 2017. Series A No. 24. I/A Court H.R., Entitlement of legal entities to hold rights under the inter-American buman rights system (Interpretation and scope of Article 1(2), in relation to Articles 1(2), 8, 11(2), 13, 16, 21, 24, 25, 29, 30, 44, 46 and 62(3) of the American Convention on Human Rights, as well as of Article 8(1)(A) and (B) of the Protocol of San Salvador). Advisory Opinion OC-22/16 of 26 February 2016. Series A No. 22.; I/A Court H.R., Rights and guarantees of children in the context of migration and/or in need of international protection. Advisory Opinion OC-21/14 of 19 August 2014. Series A No.21.; I/A Court H.R., 'Article 55 of the American Convention on Human Rights'. Advisory Opinion OC20/09 of September 29, 2009. Series A No. 20.; I/A Court H.R., Control of due process in the exercise of the powers of the Inter-American Commission on Human Rights Articles 41 and 44 to 51 of the American Convention on Human Rights). Advisory Opinion OC-19/05 of 28 November 2005. Series A No.19.

44 See e.g. IACtHR, Case of Gelman v. Uruguay (Merits and Reparations), 24 February 2011, at 229, and 238-239. The case involved an amnesty law approved by national referendum which eliminated 
In 2005, the Court rejected a request by Costa Rica for an advisory opinion on whether its Personnel legislation of the Legislative Assembly is incompatible with American Convention on Human Rights and the San Salvador Protocol on Economic, Social, and Cultural Rights. ${ }^{45}$ The Court reasoned that to issue an opinion would risk addressing litigious issues which were not yet resolved at the domestic level nor submitted to the contentious jurisdiction of the Commission or the Court. The Court cited its own jurisprudence noting:

The request should be carefully analized in order to determine, among other things, whether the aim is to help the soliciting State comply with its international human rights obligations. For such purpose, the Court should act cautiously in order to guarantee that its advisory jurisdiction will not be utilized as a tool for political debate with the aim of affecting the result of the domestic legislative process. In other words, the Court should not immerse itself in internal political disputes, which may affect the role assigned to it by the Convention. ${ }^{46}$

Furthermore, the Court indicates support for the national court to fulfill its duty regarding safeguarding human rights:

That the normative conflict presented as the antecedent to the request is based on the issue regarding the compatibility of legal limitations applied to appointment of officials within the legislative organ of the state, who have some degree of relationship to other officials or members of the legislature. The "reasonable doubt" which the State sets forth as grounds for its request is the existence of a minority vote in the resolution of an Unconstitutional Order issued by the Constitutional Court of the Supreme Court of Justice as pertaining the norm presented in the request. The Court notes the fact that the State seeks that this tribunal issue an opinion on an issue which the Constitutional Court already decided, in spite of the fact that when at the time of presenting the request, the decision was not yet publi-

the possibility of prosecution of military and police officers who participated in arbitrary detention, torture, and enforced disappearance. The Inter-American Court determined that the referendum was an act of state incurring state responsibility. See also AlmonacidArellano et al. v. Chile, IACtHR, Judgment of 26 September 2006 regarding the illegality of the amnesty law in Chile.

45 Resolution of the Inter-American Court of Human Rights on the Request for an Advisory Opinion by Costa Rica (10 May 2005) on Law No. 4556 (8 May 1970).

46 I/A Court H.R., Proposed Amendments of the Naturalization Provisions of the Constitution of Costa Rica. Advisory Opinion OC-4/84 of 19 January 1984. Series A No. 4. at para. 30. shed, only its holding was disseminated. Furthermore, not only does the request seek that the Court, by way of its advisory competence, indirectly revise what has been resolved by the Constitutional Court, but the State also requests that the Court address the scope of the norm which establishes an erga omnes character within constitutional jurisprudence vis-a-vis the American Convention and an eventual advisory opinion of the Court.

Hence the Court recognizes the role of the national judicial and legislative processes in ensuring compliance with human rights. Yet, this appears contradictory, as in this case it is the State itself which requests guidance from the Court. One would have expected that the Court would be more forthcoming in providing recommendations to the State in a non-confrontational manner, instead of indicating that the adjudication mechanism is favorable. In this case, the Court appears to support the competence of the Constitutional Court to uphold human rights.

In sum, it is possible that the Court is concerned about 'political questions', which the Court deems a matter to be more appropriately settled within the national jurisdiction, further the Court may be cautious about prompting confrontation with a State, ultimately risking withdrawal from the Court's jurisdiction. ${ }^{47}$ In contrast, the pressure on the Court to address legislation increases when the inputs come from civil society interest groups which channel their causes through the Inter-American Commission of Human Rights which in turn submits an advisory request to the Court.

\subsection{Corporal Punishment of Children}

Children's rights have received much attention from civil society groups. ${ }^{48}$ In particular, the campaign to end corporal punishment of children has been very significant. ${ }^{49}$ In 2009, the Court rejected a request by the Inter-American Commission of Human Rights to

\section{See Tsereteli, supra note 26 at 1098.}

48 See for example, Humanium, available at: < http://www.humanium.org/es/derechos/> and <http://www.deathpenaltyproject.org/where-we-operate/international/the-inter-american-courtof-human-rights / >

49 See: <http://www.endcorporalpunishment.org/> and $<$ http://resourcecentre.savethechildren.se/keyword/corporal-punishment $>$ and <http://assembly.coe.int/nw/xml/XRef/Xref-XML2HTML-EN.asp?fileid=17235\&lang=en $>$ and $<$ https: $/ /$ www. coe.int/en/web/children/corporal-punishment> and <http://hrlibrary.umn.edu/crc/comment8.html> 
address corporal punishment of children. ${ }^{50}$ This case was promoted by the Commission to generate a regional debate, given that at that time only three states within Latin America prohibited this type of punishment (Costa Rica, Uruguay, and Venezuela). The dearth of legislation indicated a lack of regional consensus, which Gerald Neuman characterizes as possibly indicating 'unresolved conflicts of values or that policy regarding new social conditions is in flux. ${ }^{51}$ However, the Court refused to issue an opinion, noting that it had addressed children's rights in its advisory opinion on The Juridical Condition and Human Rights of the Child, as well as in several of its contentious cases. ${ }^{52}$ Nevertheless, it is arguable that the jurisprudence leaves some gaps. For example, in the contentious case of The Street Children, which involved the abduction, torture, and murder of five street children in 1990 in Guatemala, the Court held the State in violation of their right to personal liberty (art. 7), right to life (art . 4), right to humane treatment (art. 5), rights of the child (art. 19), rights to judicial protection and a fair trial (arts. 25, 8 and 1(1), and violation

50 Resolution of the Inter-American Court of Human Rights on the Request for an Advisory Opinion by the Inter-American Commission of Human Rights (27 January 2009).

51 Gerald L. Neuman,' Import, Export, and Regional Consent in the Inter-American Court of Human Rights', 19 (1) The European Journal of International Law 102, 107 (2008). Tsereteli states that 'the IACtHR does not carry out a comprehensive examination of relevant national practices to establish regional consensus in support of an evolutive interpretation of human rights.' Further, she concludes 'It relies on national interpretations selectively, only when they are consistent with its own interpretation.' See Tseretelli, supra note 26 at 1100-1101 and 1104,citing Pablo Contreras, 'National Discretion and International Deference in the Restriction of Human Rights: A Comparison between the Jurisprudence of the European and the Inter-American Court of Human Rights', 28 Northwestern Journal of Human Rights 71 (2012).

52 Case of the 'Street Children ' (Villagran-Morales et al.) v. Guatemala Judgment of 19 November 1999.; I/A Court H.R., Case of Bulacio v Argentina, Merits, Reparations, and Costs. Judgment of 18 September 2003. Series C No. 100: Case of the Gómez-Paquiyauri Brothers v. Peru. Merits, Reparations and Costs. Judgment of 8 July 2004. Series C No. 110; I/A Court H.R.. Case of the Juvenile Re-education Institute v. Paraguay, Preliminary Objections, Merits, Reparations, Costs. Judgment of 2 September 2004, Series C No. 112 , Case of Bámaca-Velásquez v. Guatemala, Merits. Judgment of 25 November 2000. Series C No. 70, Case of Maritza Urrutia v Guatemala, Merits, Reparations, Costs. Judgment of 27 November 2003. Series C No. 103, Case of the Yean and Bosico Children v. The Dominican Republic, Inter-American Court of Human Rights (IACrtHR), 8 September 2005, Case of Servellón-García et al. v. Honduras, Judgment of 21 September 2006 (Merits, Reparations and Costs), Matter of Children Deprived of Liberty in the 'Complexo do Tatuape' of FEBEM, Provisional Order by the Inter-American Court of Human Rights issued to Brazil (25 November 2008). of the Inter American Convention to Prevent and $\mathrm{Pu}$ nish Torture (Articles 1,6, and 8). It was the first time the Inter-American Court identified the duty of states to adopt special measures to protect children whose rights are under threat or violated according to Article 19 (ACHR):

Every minor child has the right to the measures of protection required by his condition as a minor on the part of his family, society, and the state.

The Court stated that the right to life comprises not only the right of all persons to not being deprived of life arbitrarily, but also the right to having access to the conditions needed to lead a dignified life:

When States violate the rights of at-risk children, such as 'street children', in this way, it makes them victims of a double aggression. First, such States do not prevent them from living in misery, thus depriving them of the minimum conditions for a dignified life and preventing them from living in misery, thus depriving them of the harmonious development of their personality, even though every child has the right to harbor a project of life that should be tended and encouraged by the public authorities so that he/she may develop this project for his/her personal benefit and that of the society to which he/she belongs. Second, they violate their physical, mental and moral integrity and even their lives. ${ }^{53}$

It also based its interpretation on the UN Convention on the Rights of the Child (hereinafter CRC), noting 'Both the American Convention and the Convention on the Rights of the Child form part of a very comprehensive international corpus juris for the protection of the child that should help this Court establish the content and scope of the general provision established in Article 19 of the American Convention. ${ }^{54}$ The Court cites the CRC, Article 2 on non-discrimination, Article 3 on state protection, Article 6 on the right to life, survival, and development, Article 20 on child welfare guarantees for children deprived of family environment, Article 27 on an adequate standard of living for development, and Article 37 on the prohibition of torture, inhuman or degrading treatment, arbitrary detention, humane treatment in detention, and right to access to legal aid. The Court emphasized the scope of 'measures of protection' to include non-discrimination, 
special assistance for children deprived of their family environment, the guarantee of survival and development of the child, the right to an adequate standard of living, and the social rehabilitation of all children who are abandoned or exploited. ${ }^{55}$

Another relevant contentious case is that of Brothers Gomez Paquiyari involves the Peruvian National Police which in 1991 detained two brothers, Rafael Samuel and Emilio Moisés Gómez Paquiyauri (14 and 17 years old) in a counter-terrorism action. The boys were beaten, blindfolded, and placed in the trunk of the patrol car. While in custody, they were beaten, tortured and executed. The Court held that Peru had violated their rights to life, humane treatment, personal liberty, a fair trial, and judicial protection under the American Convention on Human Rights. By applying both the American Convention on Human Rights and the Convention on the Rights of the Child, the Court found that every child has the right to special measures of protection, and underscored that violations of children's human rights are especially grave. Governments have a special obligation to ensure that children's right to life is never threatened and there is a high standard for children's right to humane treatment. As pertaining protection of the rights of the child, the Court noted that the principle of the best interests of the child prevails, based 'on the very dignity of the human being, on the characteristics of children themselves, and on the need to foster their development, making full use of their potential'.

These decisions are supportive sources for cases involving corporal punishment of children; however they do not constitute an explicit prohibition of all corporal punishment of children.

The European Court of Human Rights addressed corporal punishment in $A v U K$ (1998), that the right of the nine year-old applicant ' $\mathrm{A}$ ' to protection from inhuman or degrading treatment had been breached, and the UK Government was responsible because of its law allowing 'reasonable chastisement'. The Court ruled that the corporal punishment inflicted on A, who had been beaten hard on several occasions with a cane, was severe enough to constitute a breach of article 3 , and that since the applicant's stepfather, who had inflicted the punishment on him, had been acquitted of assault occasioning actual bodily harm on the grounds that the punishment constituted 'reasonable chastisement', the Government

55 Para 196. had failed to provide adequate protection to the applicant and this constituted a violation of article $3 .{ }^{56}$ The legality of school corporal punishment in the UK was challenged in Campbell and Cosans v UK (1982), Y v UK (1992), and Costello-Roberts v UK (1993). ${ }^{57}$ Judge Buergenthal reflected on the symbolic importance of this issue during a visit by the Inter-American Court of Human Rights to the European Court of Human Rights:

While we were there, the European Court was
hearing a case that concerned the legality under the
European Convention of corporal punishment in
British schools. As we listened to the arguments of
the parties, one of my Latin American colleagues
leaned over to me and whispered, "if this issue ever
comes to our Court, we will know that we've solved
the human rights problems of our region..$^{58}$

In like manner to Inter-American Court of Human Rights, the European Court has not issued a judgment condemning all corporal punishment of children without exception. In conclusion, NGOs have been unable to attain regional judgments on point, in spite of their success in promoting recognition within other forums, thereby indicating a limit to transnational human rights initiatives. It is ironic that the Inter-American Court of Human Rights' rejection of the request for an advisory opinion on this issue cannot be interpreted as the Court having had success in resolving human rights problems, but instead may indicate deference to states to address these issues nationally. Civil society groups were not dissuaded by the Inter-American Court's refusal to issue an advisory opinion; they redoubled their efforts and by 2016 there were a total of ten states within Latin America which prohibit corporal punishment of children. ${ }^{59}$ Thus, the evolution of regional human rights is not dependent on the advisory output of the Inter-American Court of Human Rights; this case indicates that strategies which pursue grassroots tactics may

56 See also Tyrer $v$ UK (1978), involving a 15-year-old in the Isle of Man, the Court ruled that the judicial "birching" to which he had been subjected constituted 'degrading punishment' within the meaning of article 3 of the Convention.

57 There have also been important decisions declaring inadmissible applications challenging bans on corporal punishment in the home and in schools, Phillip Williamson and others $v$ UK (2000) this involved Christian families alleging that the ban interfered with their right to religion and family life).

58 Thomas Buergenthal, Remembering the Early Years of the InterAmerican Court of Human Rights, NYU Center for Human Rights and Global Justice, Working Paper No. 1 (2005).

59 Argentina, Brazil, Bolivia, Costa Rica, Honduras, Nicaragua Paraguay, Peru, Uruguay, and Venezuela, see: $<$ http://www.endcorporalpunishment.org/progress/prohibiting-states/> 
perhaps more successful in prompting changes through national reform initiatives. By not engaging with this issue, one may argue that the Court rendered itself superfluous and thus does not take part in the crystallization of a new human rights norm. It is possible to see the Court's uneven application of the conventionality control doctrine in the next section addressing capital punishment.

\subsection{Death Penalty}

The prohibition of death penalty has been the subject of a very successful international campaign by civil society actors and the Inter-American Commission of Human Rights, but it has proven to present legitimacy problems for the Inter-American Court of Human Rights. ${ }^{60}$ The Inter-American Commission of Human Rights published a report on the death penalty within the Inter-American system and urged the OAS Member States that have the death penalty to abolish it or to impose a moratorium on its use as a step toward abolishing it. The Commission also urges those States that have not done so to ratify the Protocol to the American Convention on Human Rights to abolish the death penalty (1990).$^{61}$ It should be noted that the suppression of capital punishment under the Protocol is not absolute. States may make a reservation in order to maintain capital punishment in the event of extremely serious offenses committed during wartime, as pursued by Brazil and Chile. As noted by Sergio Garcia Ramirez, unconditional abolition of the death penalty, in keeping with Article 13 of the European Convention on $\mathrm{Hu}-$ man Rights, is not yet the regional standard within the Americas; but once a country has abolished the death penalty it may not be reinstated- it is irrevocable. ${ }^{62}$ Hen-

60 On the civil society groups: < https://www.amnesty.org/en/ what-we-do/death-penalty/> and <https://death.rdsecure.org/ section.php?id=13> and <http://www.icomdp.org/argumentsagainst-the-death-penalty/ $>$ and $<$ http://www.icomdp.org/arguments-against-the-death-penalty/ $>$ and $<$ http://www.oas.org/ en/iachr/media_center/PReleases/2014/115.asp $>$ and <http:// congres.abolition.fr/en/> And <http://www.deathpenaltyproject. org/where-we-operate/international/the-inter-american-court-ofhuman-rights $/>$

$61<$ https://www.oas.org/en/iachr/docs/pdf/deathpenalty. pdf $>$ and <http://www.oas.org/en/iachr/media_center/PReleases/2015/062.asp. $>$ The Protocol has been ratified by ratified by Argentina, Brazil, Chile, Costa Rica, Ecuador, Honduras, Mexico, Nicaragua, Panama, Paraguay, the Dominican Republic, Uruguay, and Venezuela. (13 out of 35 states within the OAS)

62 GARCIA RAMIREZ, Sergio. 'The Inter-American Court of ce, at present the majority of OAS member states no longer have capital punishment, but a significant minority retain it. ${ }^{63}$ Antigua \& Barbuda, Bahamas, Barbados, Belize, Cuba, Dominica, Guatemala, Jamaica, and the United States retain the death penalty, and Brazil, Chile, El Salvador, and Peru have outlawed its application in ordinary crimes.

The Court successfully issued an advisory opinion in 1983 addressing restrictions to the death penalty in Guatemala, brought by the Inter-American Commission of Human Rights. ${ }^{64}$ The Court addressed the link between non-derogability and incompatibility, noting that States may make reservations to rights from which no derogation is permitted, provided the reservations do not weaken the right as a whole to a very substantial extent. ${ }^{65}$ Indeed, it set forth clear limits on expansion of death penalty. Judge Buergenthal reflected on the impact of the advisory opinion:

It was prompted by a series of summary executions in Guatemala that the government claimed did not violate the Convention's prohibition on the reestablishment of the death penalty because of its reservation to that provision. The Commission concluded that the reservation did not apply to Guatemala's action. Believing however that it would be useful for the Court to address this problem, the Commission referred the issue in a general form to the Court as an advisory opinion request. Guatemala, which had not accepted the Court's contentious jurisdiction, challenged the admissibility of the request on the ground that it was a disguised contentious case brought against it. Once the Court had ruled against Guatemala on that point, Guatemala declared in open Court that it had decided to suspend all further executions, repeatedly emphasizing that its decision had nothing to do with the Court's holding on admissibility. The executions did stop. A year earlier, Pope John Paul II on a visit to Central America had appealed, without success, to the Guatemalan authorities to stop the exe-

Human Rights and the Death Penalty',Mexican Law Review, v. 3, n. 1, p. 99-104, 2009.

63 ICAZA, Emilio Alvarez. 'The Inter-American System and Challenges for its Future', 107 American Society of International Law Proceedings, April 3-6 2013, 3,6 (ASIL 2014). See: <http://www.infoplease.com/ipa/A0777460.html>

64 I/A Court H.R., Restrictions to the Death Penalty (Arts. 4(2) and 4(4) American Convention on Human Rights). Advisory Opinion OC3/83 of September 8, 1983. Series A No. 3.

65 Thomas Buergenthal, 'The Advisory Practice of the InterAmerican Human Rights Court', Am. J. Int'l L. 79 1, 25 (1985). 
cutions. And we had succeeded with a mere advisory opinion. It was quite a morale booster for the Court. ${ }^{66}$

Unfortunately, the Inter-American Court of Human Rights was later accused of trampling on sovereignty interests when addressing death penalty within its contentious jurisdiction. Trinidad and Tobago denounced the American Convention in 1998 but the Commission filed a case with the Court (as there was a one year delay for the withdrawal to come into effect) which sought to declare Trinidad and Tobago's mandatory death penalty to be in violation of the American Convention. ${ }^{67}$ This case addressed six issues consisting of the mandatory nature of the death penalty, the process for granting amnesty, pardon, or commutation of sentence, delays in criminal proceedings, deficiencies in treatment and condition of detentions, due process violations, and denial of access to legal aid, all in connection with the criminal proceedings resulting from the alleged victims' murder convictions in Trinidad and Tobago. Although Trinidad and Tobago has not filed compliance reports with the Court, it has not executed anyone since 1999 and is subject to review by the Commission.

In 1994, Peru contested the Court's acceptance of a request for an advisory opinion by the Inter- American Commission of Human Rights on issues of state and individual responsibility involving application of the death penalty. ${ }^{68}$

The Court noted that the Commission's questions 'are general in nature and concern the obligations and responsibilities of the states or individuals who promulgate or enforce a law manifestly in violation of the

66 Thomas Buergenthal, 'Remembering the Early Years of the Inter-American Court of Human Rights', supra note 58.

67 Trinidad and Tobago: Notice to Denounce the American Convention on Human Rights (May 26, 1998), reprinted in Basic Documents Pertaining to Human Rights in the Inter-American System, Signatures \& Current Status of Ratifications of the American Convention, OAS/ser. L/V/I.4, doc. rev. 7. See Hilaire, Constantine and Benjamin et al. Case, Judgment of June 21, 2002, Inter-Am. Ct. H.R., (Ser. C) No. 94 (2002). See also I/A Court H.R., Matter of James et al regarding Trinidad and Tobago. Provisional Measures. Order of the Inter-American Court of Human Rights of April 03, 2009. See also Boyce and Joseph $v$. Trinidad and Tobago (14 June 2005). On Trinidad and Tobago's withdrawal see Natasha Parassram Concepion, 'The Legal Implications of Trinidad \& Tobago's withdrawal from the American Convention on Human Rights', in 16(3) American University International Law Review 847 (2001).

68 International Responsibility for the Promulgation and Enforcement of Laws in Violation of the Convention, Advisory Opinion, 1994, InterAm. Ct. H.R. (ser. A) No. 14, para. 12 (9 Dec. 1994).
Convention. ${ }^{99}$ The Court considered that the Commission had standing to present the request for an advisory opinion as the Commission is expected to make recommendations to States, for the adoption of progressive measures in favor of human rights within the framework of their domestic law and constitutional provisions. The Court noted that "Under those circumstances, the advisory jurisdiction of the Court can and should constitute a valuable support to enable the Commission " $[t]$ o carry out the functions "assigned to it." ${ }^{\prime 0}$ The Court held;

1. That the promulgation of a law in manifest conflict with the obligations assumed by a state upon ratifying or adhering to the Convention is a violation of that treaty. Furthermore, if such violation affects the protected rights and freedoms of specific individuals, it gives rise to international responsibility for the state in question.

2. That the enforcement by agents or officials of a state of a law that manifestly violates the Convention gives rise to international responsibility for the state in question. If the enforcement of the law as such constitutes an international crime, it will also subject the agents or officials who execute that law to international responsibility.

Moreover, the Court's jurisprudence places emphasis on the avoidance of arbitrary application of the death penalty, respect for procedural guarantees (including due process, in accordance with Article 8 and 25), application to only the most serious crimes (not political crimes), and respect for the principles of necessity and proportionality.

Nonetheless, in 2005, the Inter-American Court appeared to retreat from expanding the use of the advisory jurisdiction in pursuit of the conventionality control doctrine, as it refused a request by the Inter American Commission of Human Rights for an advisory opinion regarding whether states have an obligation to provide judicial remedies to persons sentenced to the death penalty. ${ }^{71}$ The Commission raised this because Barbados, Belize, and Jamaica had enacted what Judge Garcia Ramirez describes as 'excessive legislation' relating to the death penalty that was deemed to violate human rights

\section{Ibid at para. 24.}

70 Ibid at para. 25.

71 Resolution of the Inter-American Court of Human Rights on the Request for an Advisory Opinion by the Inter-American Commission of Human Rights, 24 June 2005. In comparison see Reid $v$ Jamaica Communication No. 250/1987, Views adopted on 20 July 1990 at para 11 .5, U.N. Doc. CCPR/C/51/D/355/1989 (1994). 
standards. ${ }^{72}$ The Inter-American Court rejected the request and noted that had already addressed the death penalty in a previous advisory opinions, provisional measures, as well as contentious cases. Hence, it called upon the Commission to review this jurisprudence in order to glean the answer to its questions and noted that this jurisprudence should also serve as a guide to States (including those who were not parties to the case). ${ }^{73}$

At present, the Inter-American Court appears to be very cautious about risking the alienation of Member States, in spite of the fact that there is growing concern about the increased penalties (including death penalty) being applied to transnational crime (such as narco-trafficking and kidnapping), terrorism, and gang related violence within the region. ${ }^{74}$ There is a clear tension between the civil society push to attain an international moratorium on the death penalty and the right of states to determine their national penal systems as a means of guaranteeing security to their citizens.

\subsection{Impeachment}

Perhaps one of the most pressing tests of a state's level of democracy is that of the process of impeachment. Impeachment is a marker of institutional instability and inter-branch conflict. The recent impeachment of the President of Brazil, Dilma Rousseff was a striking attack by the Congress. ${ }^{75}$ This section will

72 Sergio Ramirez, 'La Pena de Muerte en la Convencion Americana sobre Derechos Humanos y en la Jurisprudencia de la Corte Interamericana', Boletin Mexicano de Derecho Comparado, No. 114 Sept-Dec. 2005, available at: <https://revistas.juridicas.unam.mx/ index.php/derecho-comparado/article/view/3853/4820>.

73 See I/A Court H.R., Restrictions to the Death Penalty (Arts. 4(2) and 4(4) American Convention on Human Rights). Advisory Opinion OC-3/83 of 8 September 1983. Series A No. 3. See I/A Court H.R., The Right to Information on Consular Assistance in the Framework of the Guarantees of the due Process of Law. Advisory Opinion OC-16/99 of 1 October 1999. Series A No.16. See also the contentious case Boyce et. Al. v. Barbados 20 Nov. 2007.

See also Da Costa Cadogan v. Barbados (2009). See also: Raxcacó Reyes v. Guatemala (15 September 2005). See also Fermín Ramírez v. Guatemala (20 June 2007).

74 See press release by UN Special Rapporteur on the promotion and protection of human rights and fundamental freedoms while countering terrorism, Ben Emmerson denouncing the use of the death penalty in cases involving terrorism: <http://www.ohchr.org/EN/NewsEvents/Pages/DisplayNews. aspx?NewsID=20659\&LangID=E https://www.un.org/press / en/2016/gashc4189.doc.htm>

75 Gretchen Helmke notes that '. . . Countries heading the list in terms of the total number of inter-branch threats or attacks are also some of Latin America's most distressed democracies: Ecuador, provide an overview of the impeachment process, the presentation of a request by the OAS Secretary General to the Inter American Court of Human Rights for an Advisory Opinion, the Inter-American Democratic Charter and the Right to Democracy, and a comparison to the removal of judges.

\subsubsection{The Impeachment of President Rousseff}

On 15 October 2016 three lawyers within the Chamber of Representatives filed for impeachment based on President Rousseff's alleged responsibility for failing to properly respond to a corruption scandal involving Petrobas and the embezzlement of funds directed to her political party, charges of 'fiscal pedaling', as well being as violation of the Annual Budgetary Law due to her issuance of six decrees which provided credits to social programs without first obtaining Congressional authorization. $^{76}$

The Brazilian Constitution (1988) sets forth a process in which the speaker of the lower chamber of Congress, in this case Eduardo Cunha (a political opponent of Ms. Rousseff), had to accept a petition for impeachment. Mr. Cunha then formed a 65-member congressional committee to investigate the accusations and decide if removal was warranted. The committee was created in December, but the court ordered it to suspend proceedings. The committee later resumed its work and in a 38-27 vote on 11 April, approved to move for a vote on her impeachment in Brazil's Chamber of Deputies. On 17 April 17, the lower chamber voted for impeachment. An important point of contention is that in early May, the Supreme Federal Court removed Mr. Cunha from his speaker role on charges of obstructing the corruption investigation. After the lower chamber vote, the process then moved to the Senate, which had

Venezuela, Paraguay, Bolivia, and Argentina.' Gretchen Helmke, 'The Origins of Institutional Crises in Latin America: A Unifies Strategic Model and Test', paper prepared for the Workshop on the Rule of Law, Yale University, 28-29 March 2008.

76 Petrobas is a semi-public Brazilian multinational corporation in the petroleum industry. 'Fiscal pedaling' is a financial practice that consists of transferring delay of federal public resources to public financial institutions to boost government financial reports. Public banks had to pay with their own funds, and then be reimbursed by the government once the public treasury had more funds. Since the government had not made the payment, the market considered the government to have more funds than it actually had. See also: <https://www.ft.com/content/6e8b0e28-f728-11e5-803cd27c7117d132> 
to decide, with a simple majority vote, whether to accept the charges. On 12 May, the Senate voted 55 to 22 to begin the trial, resulting in Ms. Rousseff's suspension. The vice president, Michel Temer, then took over, with the authority to appoint ministers and enact policy. The Senate trial was overseen by the chief justice of the Supreme Federal Court, Ricardo Lewandowski. Two-thirds of the 81 senators were required vote in favor of removing the president from office. As 61 senators voted in favor, 20 against, President Rouseff was removed from office. It was concluded that that she had violated fiscal laws by using funds from state banks to cover budget deficit spending. Mr. Temer will serve as president for the remainder of Ms. Rousseff's term through the end of 2018 but will not be able to run for president in the next election. President Rousseff claimed that she was a victim of a coup d'etat, noting 'They've just overthrown the first woman elected president of Brazil, without there being any constitutional justification for this impeachment. ${ }^{77}$ However, the senators voted 42 to 36 to allow Rousseff to maintain her political rights, hence she can continue to stand in elections and hold public office in the future.

In comparison, the European Court of Human Rights has not addressed the legality of impeachment proceedings, but held that there was a violation of Article 3 of Protocol Nr. 1 in a case in which the former President of Lithuania had been impeached and was subsequently barred from running for elected office within the Parliament permanently and irreversibly. ${ }^{78}$ The Court considered this to be disproportionate, as there should have been a time limit and process of review of the measure.

Rouseff's defense argued that the law does not cover negligent crimes of responsibility (it has also been suggested that fiscal pedaling at 2015 was not yet recognized as a crime, nullem crimen nulla poena sine lege praevia, and its lack of precision makes it unlikely to be considered a crime according to the principle of legality. Further, they argued that Rouseff acted under the advice of experts, hence she lacked criminal intent. Finally, they stated that Cunha approved of the impeachment in order to retaliate for Rouseff's refusal to support votes in his favor on the Ethics Committee when he

\footnotetext{
77 <http://www.democracynow.org/2016/9/1/dilma_rousseff_on_ouster_this_is $>$

78 Paksas v. Lithuania, no. 34932/04, ECtHR 6 January 2011.
}

was subject to trial for his involvement in the Petrobas scandal and the discovery of secret accounts in Switzerland. In fact, his acceptance of the impeachment came hours after Rouseff announced that her party would not vote in his favor at the trial. Vice-president Temer assumed the presidency and promptly enacted a series of neo-liberal reforms, stating in the media that the impeachment process had actually been pursued as a means of enabling these reforms to occur. ${ }^{79}$ As noted by Professor Bircovici, the vagueness of the grounds for impeachment appears to have enabled a shift in the system of checks and balance among the branches of government:

The fact that a government is unpopular or
without parliamentary majority to its policies
does not justify, necessarily, the initiation of the
impeachment process. The impeachment is not a
vote of confidence, as occurs in the parliamentary
system, in the same way that does not constitutes a
'recall' or a form of popular revoking of an elective
office. The respect to the popular choice made in
the polls is essential in any Democratic State of
Law. The impeachment process must always be the
last measure, a power to be exercised with extreme
cautious in extreme cases of proven Constitution
violation, and must have the majority support from
the society, not only from a parliamentary majority
exasperated or manipulated by economic and
political interests [...]. ${ }^{80}$

There are clear divisions of opinion about the legality and legitimacy of the impeachment process among Brazilian legal and political experts and thus there emerged a state of crisis regarding the state of democracy. ${ }^{81}$

\subsubsection{The OAS Secretary-General's Extraordinary Request of an Advisory Opinion}

The OAS Charter, Article 2 (b) sets forth that one of the purposes of the OAS is to '...promote and con-

79 'Temer diz que Dilma sofreu impeachment porque rejeitou projeto neoliberal' (23 September 2016). Pragnmatismo Político. Retrieved from: <http://www.pragmatismopolitico.com.br/2016/09/ temer-dilma-sofreu-impeachment-rejeitou-projeto-neoliberal.html $>$ 80 Gilberto Bercovici (2015), 'Parecer do Impeachment da Presidenta Dilma Rousseff', pp. 8-9; available at: < http://s.conjur.com. $\mathrm{br} / \mathrm{dl} /$ parecer-dilma-bercovici.pdf http://politica.estadao.com.br/ blogs/fausto-macedo/juristas-dizem-que-impeachment-sem-crimede-responsabilidade-atinge-constituicao/ >

81 Professor of Constitutional Law, Pedro Serrano stated that the impeachment of Dilma Rousseff is an 'attack to the democracy' and that violates treaties involving the Inter-American Court of Human Rights. Fellet, J. (15 August 2016). 'Quais as chances de Dilma conseguir anular o impeachment na OEA?’ BBC Brasil in Washington. 
solidate representative democracy.' Judge Garcia-Sayen confirms 'since the inception of the OAS, democracy and respect for the essential human rights were conceived as interdependent. ${ }^{92}$ On April 15, 2016, the OAS Secretary General, Luis Almagro, issued a statement denouncing the impeachment process in Brazil as political in nature, as it was based on poor administration of public resources instead of a criminal accusation, and further expressed concern for the constitutional implications of this process $^{83}$ :

In addition, it must be highlighted that a presidential system like the one in Brazil-and the vast majority of those in our Hemisphere, except for the English-speaking Caribbean - cannot operate out of the blue as if it were a parliamentary system, moving for impeachment, in this case of the chief executive, because of a shift in the political balance of a coalition government.

In effect, the sustainability of the presidential system does not depend solely on the legislature and the alliances generated therein. This is a reality that is useful in terms of efficiency in legislating and governing, but does not substitute for popular and sovereign support generated at the moment of voting for the current President. This equation of popular sovereignty cannot be changed for politically opportunistic reasons. If those who wrote the Constitution had wanted to establish a kind of parliamentary or semi-parliamentary solution, they would have structured it in that way and the logic of formation of governments, designation of the cabinet, the political responsibility and the fall of governments would be completely different.

We are not making a judgment as to which kind of system-presidential or parliamentary-is better, because that depends on the social and political contract of every society. But the organization of the Brazilian constitutional system is clear and, for that reason, it has established the constitutional limits for the exercise of an impeachment process. To ignore those limits affects the very structure of how the system operates, and distorts the forces and operation that the Constitution and the laws should have.

In pursuit of an extraordinary recourse, given the

82 Separate Opinion of Judge Garcia-Sayan, Inter-American Court of Human Rights, YATAMA Case, Series C. No. 107 (2004) at para. 4.

$83<$ http://www.oas.org/en/media_center/press_release. asp?sCodigo $=\mathrm{E}-044 / 16>$ gravity of the situation, the OAS Secretary General requested an advisory opinion from the Inter-American Court regarding the due process rights of the President of Brazil, Dilma Rousseff during impeachment proceedings against her. The fact that the OAS Secretary-General felt compelled to turn to the Court for assistance indicates the gravity of the situation.

He asked the Court to indicate: 'the specific criteria which should be guaranteed, as regarding separation of powers, that there should be due process in cases of impeachment of a national authority, the seriousness of the causes which could justify such action, taking into consideration the impact this has on respect for the popular will in choosing its representatives, the situation of this person during the proceeding in which she should be presumed innocent, with the aim of avoiding resulting in a violation of human rights and a serious change of the principles which apply to the entire democratic system.' The Secretary-General requested that the Court specify 'which actions or changes to due process, such as previous declarations which would indicate prejudice by those who have to decide the case in last instance, and what would be the consequences on the validity of this process.'

He asked the Court to issue an opinion on several issues which could substantively affect the due process rights in impeachment, and what would be the consequences of:

a) Statements made when voting by those who have to decide the opening of the impeachment process and appear to prejudice, moving ahead condemnation opinions or forgiveness or expressing grounds which are unrelated to the issue under consideration;

b) The specific recognition on the part of these persons as to their following instructions, to the detriment of the required level of impartiality;

c) The invocation of common causes for various officials instead of for one individual,

d) The charge for events that could have been carried out at a time earlier than that which would be relevant from the legal perspective.

Finally, the Secretary-General indicated that it was absolutely urgent that the Court address the legality of the reasons invoked to pursue the impeachment of President Dilma Rouseff and the possible violations conducted in the Chamber of Representatives which 
approved the documents of the Special Commission, of the connection of the votes by the representatives motivated by reasons which were unrelated to the charge submitted to the Chamber, as well as the partisan circumstances which inhibited legislators to take a position in conformance with their own personal convictions. He noted that the opinion of this body would be absolutely relevant to the effect of the decisions which the Secretary-General should take in conformance with the obligations which are set forth in the Inter-American Democratic Charter for the Secretary General according to Article 20(1).

The Inter-American Court is recognized for being a strong voice against impunity and defender of due process rights. Rather than accept the invitation to support diplomatic efforts to address the impeachment crisis, the Court declined the request. On 23 June 2016, The Inter-American Court grounded its rejection by stating that the request for an advisory opinion risked the issuance of a premature opinion given the fact that the case may be subjected to contentious proceedings in the future and that the matter had not yet been resolved at the domestic level. ${ }^{84}$ The deference to the national system is an indication of the delicate balance the Court must maintain while operating in what Tom Gerald Daly describes as "transnational" judicial space, with the courts at the domestic and regional levels working together as part of a common judicial project to constrain arbitrary state action and uphold human rights. ${ }^{95}$ Daly states that the Brazilian Supreme Federal Court does not often refer to the Inter-American Court of Human Rights jurisprudence and is critical of its lack of deference to the national court. ${ }^{86}$ The Court also reminded the Secretary-General that Article 20 of the Inter-American Democratic Charter specifically recognizes the mandate of the Secretary-General to take action to address these types of issues, hence rendering the need for an advisory opinion superfluous.

84 Resolution of the Inter-American Court of Human Rights on the Request for an Advisory Opinion by the OAS Secretary General 23 June 2016.

85 Tom Gerald Daly, 'Brazilian 'Supremocracy'and the InterAmerican Court of Human Rights: Unpicking an Unclear Relationship.' P. Fortes et al. (eds) Law and Policy in Latin America.3-4 (Palgrave Macmillan UK, 2017).

86 Id. at 5 and 15. See Gomes Lund et al. v. Brazil, Judgment of 24 November 2010 (Preliminary Objections, Merits,

Reparations and Costs), para. 44. The Inter-American Court of $\mathrm{Hu}-$ man Rights contests the Supreme Federal Tribunal's approval of an amnesty law.
Given, the lack of action by the Court, on 9 August 2016 the Brazilian Workers Party requested a precautionary measure from the Inter-American Commission of Human Rights to suspend the impeachment trial due to violations of due process and the lack of possibility of judicial review. ${ }^{87}$ On 2 September 2016, the Inter-American Commission on Human Rights expressed concern over the impeachment process, in particular accusations about irregularities, arbitrariness, and lack of due process guarantees. ${ }^{88}$ However, it did not issue an immediate precautionary measure; hence the impeachment process was unimpeded. It may be that the Commission was cautious regarding Brazil because it was undergoing a severe financial crisis on account of Brazilian withdrawal of funding pursuant to the Commission's decision of 2011 ordering provisional measures to suspend the Belo Monte Dam Complex in the Amazonian state of Para, citing the project's potential harm to the rights of traditional communities living within the Xingu river basin. ${ }^{89}$ Nonetheless, the Commission indicated that it was concerned with the Brazilian Judiciary's monitoring and supervision functions in this case and the ramifications of the impeachment as pertaining President Rousseff's rights. In September 2016, Rousseff appealed to the Supreme Federal Tribunal, but it rejected the petition in October 2016..$^{90}$

A chilling turn of events occurred after the impeachment, as one of the Supreme Federal Court judges, Teori Zavascki died in a plane crash in January 2017. The judge was expected to rule on the eligibility of plea bargain testimonies by 77 Odebrecht executives which would implicate the several top politicians, including President Temer and Senate President Renan Calheiros (next in line to Temer). ${ }^{91}$ This resulted in significant concern about the fragility of institutions and rule of law in Brazil, as there is uncertainty as to how the corruption

87 <http://www.pt.org.br/wp-content/uploads/2016/08/cidh_ dilma_petition_executive-summary.pdf $>$

$88<$ http://www.oas.org/en/iachr/media_center/PReleases/2016/126.asp $>$

$89<$ http://amazonwatch.org/news/2016/0107-iachr-openscase-against-brazil-for-human-rights-violations-related-to-belomonte-dam>; see also <http://latindispatch.com/2011/05/03/ brazil-breaks-relations-with-human-rights-commission-over-belomonte-dam/>

90 André Richter (20 October 2016). 'Supreme Court Justice denies appeal to cancel Dilma Rousseff's impeachment.' Agência Brasil. 91 Odebrecht is a Brazilian construction company implicated in the Petrobas corruption scandal, see: <http://www.wsj.com/ articles/marcelo-odebrecht-agrees-to-plea-deal-in-brazilian-corruption-probe-1480624125> 
investigation will manage to continue after the loss of the judge. One may suggest that by rejecting the OAS Secretary General's request for an advisory opinion, the Inter-American Court of Human Rights missed an opportunity to provide supportive guidance to the his office during the impeachment crisis which revealed a high level of institutional instability (including within the national judiciary and at the democratic/constitutional crisis level) in the biggest country within Latin America. It is possible to argue that the case would be more appropriate for the contentious jurisdiction, but the urgency of situation indicates that it may have benefited from an intervention from the Court to address the legal issues which had been overshadowed by high tension politics. Indeed, the Court could have chosen to approach the request as addressing an issue which was of 'acute concern to the OAS', in like manner the ICJ's refutation of Israel's contestation of advisory jurisdiction in the Wall case on account of the interest of the United Nations. ${ }^{92}$ Lamentably, instead of an advisory opinion, the Inter-American Court of Human Rights issued a statement calling for an especially careful and timely investigation of the circumstances the plane crash, given the judge's role in important national proceedings. ${ }^{93}$

\subsubsection{The Inter-American Democratic Charter and the Right to Democracy}

The Inter-American Court of Human Rights made reference to the fact that the Inter-American Democratic Charter (2001) establishes a specific procedure for situations involving the alternation of a constitutional regime which involve other organs within the OAS, including the Secretary-General, the Permanent Council and the General Assembly:

Article 20

In the event of an unconstitutional alteration of the constitutional regime that seriously impairs the democratic order in a member state, any member state or the Secretary General may request the immediate convocation of the Permanent Council to undertake a collective assessment of the situation and to take such decisions

92 Advisory Opinion Concerning Legal Consequences of the Construction of a Wall in the Occupied Palestinian Territory, International Court of Justice (ICJ), 9 July 2004, 151-52, para. 47, cited by Calidonio Schmid, supra note 1 at 429.

$93<$ http://www.corteidh.or.cr/docs/comunicados/cp_02_17. $\operatorname{pdf}>$ as it deems appropriate.

The Permanent Council, depending on the situation, may undertake the necessary diplomatic initiatives, including good offices, to foster the restoration of democracy.

If such diplomatic initiatives prove unsuccessful, or if the urgency of the situation so warrants, the Permanent Council shall immediately convene a special session of the General Assembly. The General Assembly will adopt the decisions it deems appropriate, including the undertaking of diplomatic initiatives, in accordance with the Charter of the Organization, international law, and the provisions of this Democratic Charter.

The necessary diplomatic initiatives, including good offices, to foster the restoration of democracy, will continue during the process.

\section{Article 21}

When the special session of the General Assembly determines that there has been an unconstitutional interruption of the democratic order of a member state, and that diplomatic initiatives have failed, the special session shall take the decision to suspend said member state from the exercise of its right to participate in the OAS by an affirmative vote of two thirds of the member states in accordance with the Charter of the OAS. The suspension shall take effect immediately.

The suspended member state shall continue to fulfill its obligations to the Organization, in particular its human rights obligations.

Notwithstanding the suspension of the member state, the Organization will maintain diplomatic initiatives to restore democracy in that state.

This supports the perspective that the Court may have been correct to pursue a 'political question' approach to reject the request for the advisory opinion. Nevertheless, it is also possible to argue that the OAS Secretary General may have been overwhelmed by the intensity of the impeachment crisis and sought institutional backing from the Court.

The Inter American Democratic Charter had been proposed by the transitional government in Peru that had succeeded Alberto Fujimori in order der to prevent further attacks on democracy within the region. It was noted that 'the peoples of the Americas have a right to democracy and their governments have an obligation to 
promote and defend it. ${ }^{94}$ The charter has been invoked in response to coups-the failed one against President Hugo Chávez in Venezuela in 2002 (but Chavez was reinstated before the OAS General Assembly met) and a successful one against Manuel Zelaya of Honduras in 2009. The OAS General Assembly convened a special meeting and suspended Honduras' membership.

It has been noted that the test of the Inter American Democratic Charter is whether the OAS organs will apply it to sitting officials who violate democratic norms. ${ }^{95}$ The Charter has not yet been applied to impeachment cases; hence it is uncertain whether the Inter-American Court of Human Rights is correct in deferring to the other institutions. The Inter-American Democratic Charter preamble states 'One of the purposes of the OAS is to promote and consolidate representative democracy'. As an OAS institution, it is arguable that the Court has an obligation to assist other OAS organs when requested to support a crisis brought about by inter-branch conflict. Indeed, Judge Garcia-Sayen observed:

'It is a well-known fact that the list of human rights has never been static. It has gradually been defined and embodied in legal instruments with the development over time of society, the organization of the State, and the evolution of political regimes. This explains why we are currently seeing the development and expansion of political rights, and even what some have called the "human right to democracy." This development is expressed in the Inter-American Democratic Charter, the juridical instrument that the inter-American system has engendered to strengthen democracy and related rights. Its first article stipulates that: "The peoples of the Americas have a right to democracy and their governments have an obligation to promote and defend it. ${ }^{396}$

94 <http://www.economist.com/blogs/americasview/2011/01/ inter-american_democratic_charter>

95 See Rubén M. Perina, 'The Inter-American Democratic Charter An Assessment and Ways to Strengthen It', available at: < https:/ / www.oas.org/en/spa/democracia/docs/Brooking_\%20Inter $\% 20$ Am\%20Demo\%20Charter $\% 20 \% 20$ RMP $\% 20 \% 20 \% 12 \% 20$ pdf.pdf $>$ He notes that the definition of an 'unconstitutional interruption' remains unclear and that that members of judicial and legislative organs should be able to address the OAS. The IADC recognizes the elements of representative democracy as including: respect for the rule of law; human rights and fundamental freedoms; periodic, free and fair elections; a pluralistic system of political parties; the separation and independence of powers; fundamental democratic core values and practices, such as probity and transparency in government activities; respect for diversity; and citizen participation. See also: $<$ http://www.oas.org/en/iachr/media_center/crisis-graphs.asp $>$ 96 Separate Opinion of Judge Garcia-Sayan, Inter-American Court of Human Rights, YATAMA Case, Series C. No. 107 (2004)
Furthermore, Charter sets forth additional guarantees recognizing a link between human rights and democracy that implies a relevant role for the Court. ${ }^{97}$ :

Article 3: 'Essential elements of representative democracy include, inter alia, respect for human rights and fundamental freedoms, access to and the exercise of power in accordance with the rule of law, the holding of periodic, free, and fair elections based on secret balloting and universal suffrage as an expression of the sovereignty of the people, the pluralistic system of political parties and organizations, and the separation of powers and independence of the branches of government.'

Article 7: 'Democracy is indispensable for the effective exercise of fundamental freedoms and human rights in their universality, indivisibility and interdependence, embodied in the respective constitutions of states and in inter-American and international human rights instruments.'

In comparison, we may consider the role of the Court in the example of a case involving the removal of a judge.

\subsubsection{The Removal of Judges}

The removal of judges can signal problems with the independence of the judiciary and thus indicate democratic weakness. There are various institutions within the OAS that may address the removal of judges. In May 2016, Human Rights Watch called upon the OAS Secretary General to invoke the Inter-American Democratic Charter in relation to the Venezuelan government's interference with the independence of the judiciary. ${ }^{98}$ Venezuela's National Assembly (AN), formally asked the OAS Secretary General to apply the Inter-American Democratic Charter in view of the country's economic and political situation. This included the economic crisis, the de facto control by president Maduro of the Judiciary and Electoral branches of government, a decree of 'state of exception and economic emergency' passed without the approval of the $\mathrm{AN}$, and threats made by

at para. 7

97 See also Thomas M. Franck, 'The Emerging Right to Democratic Governance'

86 (1) The American Journal of International Law, (Jan., 1992), pp. 4691.

98 <https://www.hrw.org/news/2016/05/16/venezuela-oasshould-invoke-democratic-charter $>$ 
President Maduro to close down the AN and prevent a recall referendum promoted by the opposition. In turn, the OAS Secretary General called an emergency meeting of the Permanent Council of Member States to discuss the situation in Venezuela. ${ }^{99}$

The Inter-American Court of Human Rights has also been asked to address the removal of judges within its contentious jurisdiction, Case of the Constitutional Tribunal (Camba Campos et. Al.) v. Ecuador (Judgment of 28 August 2013). The Court found violations of Article 8 in relation to Article 1, and Article 23 on account of the arbitrary termination and removal proceedings in violation of judicial guarantees, as well as having arbitrary effects on the exercise of the judicial function and harm to judicial independence and the guarantee of impartiality. The Court noted that Ecuadoran law expressly prohibited the prosecution of members of the Constitutional Tribunal based on the legal content of their opinions and on the Legislatures' disagreement with a judicial ruling. The Court cited Art. 3 of the Inter-American Democratic Charter which sets forth that essential element of representative democracy is the separation of powers and independence of the branches of government:

The Court concludes that the dismissal of all the members of the Constitutional Tribunal entailed a destabilization of the democratic order that existed at that time in Ecuador, because the attack on the three high courts of Ecuador at that time resulted in a rupture of the separation and independence of the branches of governments. The Court stresses that the separation of powers is closely related not only to the consolidation of the democratic system, but also seeks to preserve the human rights and freedoms of the people.

This is a very important decision which serves as a clear example of the Inter-American Court's role as a guarantor of democracy as a foundation for the enjoyment of human rights in the region. The Court's reluctance to address the case of impeachment of a sitting president stands in contrast its strong engagement in the case of the removal of a judge. Both cases address the state of democracy and separation of powers, as well as human rights, nevertheless it possible to argue that the Court would prefer the presidential case to be presented under the contentious jurisdiction, as was the case

$99<$ http://www.oas.org/en/media_center/press_release. asp?sCodigo $=\mathrm{E}-068 / 16>$ involving the judge. Alternatively, the Court may have been concerned that Brazil may seek to withdraw support from the Court as it did with the Commission. ${ }^{100}$

\section{Final Considerations}

Although the four rejections of requests for advisory opinions may be described as evidence of strategic prudence by the Court, it is indeterminate whether the Inter-American Court will continue to develop the scope of the advisory opinion in either a broad or narrow manner. ${ }^{101}$ It may be argued that the Court, as other international tribunals, is more likely to follow sine wave patterns, rather than linear paths when addressing political cases. International courts within both human rights and international criminal law are increasingly being challenged; the ICC has received notices of withdrawal from Russia, South Africa, Burundi, and Gambia, and the African Court of Human Rights suffered the withdrawal of Rwanda. The Inter-American Court itself underwent threats of withdrawal from Venezuela, Ecuador, and Peru. ${ }^{102}$

The ICC has sought to embark on a strategy of creative expansion of investigation of crimes in order to address environmental harm and damage to cultural property, perhaps to underscore its continued relevance or added value in normative analysis. ${ }^{103104}$ Similarly, the PCA addressed the duty to conduct Environmental Impact Assessments in the Philippines v. China case. ${ }^{104105}$

100 <http://latindispatch.com/2011/05/03/brazil-breaks-relations-with-human-rights-commission-over-belo-monte-dam/>

101 Buergenthal stated 'Whether the scope of the Court's advisory jurisdiction will expand further or begin to contract is closely related to the perceived needs of the inter-American system for the protection of human rights.' He set forth that If more states and the Commission submit more contentious cases to the Court, 'resort to its advisory jurisdiction may decline and its importance diminish.' Buergenthal, The Advisory Practice of the Inter-American Human Rights Court, supra note 64 at 26.

102 See generally: < http://interamericanhumanrights.org/background/challenges-and-criticisms/>

$103{ }^{104}$ The ICC issued a decision cultural destruction of property in the Ahmad al-Faqi al-Mabdi case. It issued a statement that it would pursue investigation of cases involving crimes that result in the 'destruction of the environment', 'exploitation of natural resources' and the 'illegal dispossession' of land. <https://www. theguardian.com/global/2016/sep/15/hague-court-widens-remitto-include-environmental-destruction-cases $>$

104105 See: $<$ http://www.ejiltalk.org/environmental-aspects-ofthe-south-china-sea-award/> 
It may be argued that the Inter-American Court has chosen to follow a parallel strategy with its Advisory Opinion on the Environment and Human Rights (2017) that also upheld the duty to conduct Environmental Impact Assessments. On the other hand, given the current climate of emphasis on sovereignty and backlash against human rights, the Court may wish to show deference to states and avoid controversial decisions. ${ }^{105106}$ The Court and the Commission are both facing funding crises and this has already resulted in a temporary complete halt of cases in the latter institution. ${ }^{106107} \mathrm{It}$ remains to be seen which strategic choice the Court will pursue, and it may well continue to display mixed approaches, although it may be that the Court may seek to rely more on the contentious jurisdiction to address complex, political claims in deference to the principle of consent. The case examples of restraint signal a possible reluctance to utilize the advisory jurisdiction to expand the interpretation of human rights when led by civil society or consolidate democracy. Nevertheless, the Advisory Opinion on Gender Identity, and Equality and Non-Discrimination with regard to Same-Sex Couples (2017) indicates otherwise. There is an open question as to whether there will be significant backlash to this opinion and in turn, whether the Inter-American Commission of Human Rights will choose to focus even more on pursuing contentious case, leaving the advisory jurisdiction as a mechanism for states to check on normative consultation. There is a tension between the conventionality control doctrine and the limitation of the Court's advisory jurisdiction, and this in turn may have unintended consequences.

$105{ }^{106}$ Thomas Carothers, 8(3) 'Closing Space for International Democracy and Human Rights Support.' In J Human Rights Practice 358-377 (2016); see also Inter-American Human Rights Network, 'Strengthening the Impact of the Inter-American Human System Through Scholarly Research' 5 (April 2016) available at $<$ http:/ discovery.ucl.ac.uk/1478296/1/ReflectiveReport-web.pdf> (page 5) $106107<$ http://nobelwomensinitiative.org/inter-american-human-rights-system-underfunded/ $>$ As a matter of fact, both the Court and the Commission are chronically underfunded institutions subject to frequent and public criticism and threats of withdrawal by OAS member states, particularly in reaction to controversial Court rulings. 
Para publicar na Revista de Direito Internacional, acesse o endereço eletrônico www.rdi.uniceub.br ou www.brazilianjournal.org.

Observe as normas de publicação, para facilitar e agilizar o trabalho de edição. 